\title{
Childhood Lost: Children of the Leningrad Blockade
}

\author{
MiKAEL ZAKHAROV \\ University College London
}

\begin{abstract}
My essay explores the impact the blockade of Leningrad had on childhood experience and development. I argue that the blockade had a profound effect on the mental and physical development of children. Many children were forced to grow up ahead of their years and take on adult responsibilities. Family roles were reversed as children worked in order to support their family and became caregivers for their parents. In other words, children were thrust into the unknown world of adulthood ahead of their time, skipping a vital developmental stage. Starvation affected the physical development of children by delaying puberty and stunting growth. For my research, I relied heavily on the diaries and memoirs of children who lived through the siege of Leningrad. In total I used 26 diaries and ten memoirs, as well as a large number of secondary sources. Diaries provide an interesting and personal take on the blockade.
\end{abstract}

\section{INTRODUCTION}

The Leningrad blockade began on 8 September 1941. The city was under siege for 872 days during which time an estimated 800,000 civilians died. At the start of the blockade 400,000 children remained trapped within the city. Those who lived during the siege suffered from the city's lack of food and fuel. A rationing system was put in place making food mainly available through ration cards. In the first months of the blockade alone, rations were slashed five times. On a daily basis German artillery kept the city under constant fire, causing further distress for the people. As the historian john barber notes, 'Leningrad suffered the greatest demographic catastrophe ever experienced by one city in the history of mankind'.2 In this work, I will focus specifically on the plight of children during the blockade and how their childhood was impacted by the war. I will look primarily at the first year of the blockade: first, because the conditions were harshest during this period and second, because most children were evacuated in the spring of 1942. The work will begin by analysing the perception of

1 Food could be bought with money up until beginning of November 1941 in canteens and shops, after this point food could only be obtained through ration cards, or on the black market.

2 Alexis Perri, The War Within (Cambridge, Massachusetts: Harvard University Press, 2016), p.4. 
childhood in pre-war Soviet Union and how this changed with the onset of war. I will then look at different survival methods adopted by children and how the blockade aged the children both physically and mentally. Finally, I will explore the aftereffects of the blockade, how the war changed their lives forever.

\section{SOURCES AND HISTORIOGRAPHY}

\section{Primary Sources}

My research essay relies heavily upon diaries and memoirs, written by those who survived the blockade as a child. I found diary excerpts in Deti Goroda Geroia (Children of the Hero City), while Detskaya kniga voiny (The Children's Book of War) provided me with 26 complete children's diaries from the siege, many published for the first time. A team of reporters from the newspaper Argumenty $i$ Fakty (Arguments and Facts) collected these diaries in order to create a better understanding of the childhood experience during the war. The newspaper's lead editor explains, 'We wanted to look at a subject which has rarely been explored, apart from the name of Tanya Savecheva and one or two hero Pioneers, we know nothing about the experiences of children during the war.'3

The practice of diary writing is one that is deep rooted in Russian and Soviet tradition. During the 1930s many Soviet people adopted this medium 'to monitor their own physiological and intellectual processes for the purpose of controlling and perfecting them'.4 In other words, diaries were used to help people become ideal Soviet citizens. However, during the siege, the aim of diary writing changed. Diaries were instead used 'to preserve traces of themselves in the face of annihilation'.5 The resulting diaries are more sincere. And according to Daniil Granin, children's diaries are even more honest and therefore 'their declaration and testimony, are much more valuable to historians than the diaries of adults'.6

Using diaries as historical sources has many advantages and disadvantages. Diaries are personal and so offer a glimpse into an individual's life, but they also can present an insight into the social context of the time. As Irina Paperno explains, 'The diary can be said to create a space for the intimate

3 Detskaya kniga voiny, ed. by Nikolay Zyatkov, Evgeny Faktorovich, Tatyana Kuznetsova, Polina Ivanushkina, and others (Moscow: Argumenty i Fakty, 2016), p. 5.

4 Jochen Hellbeck, Revolution on my mind (Cambridge, Massachusetts: Harvard University Press, 2006), p. 78.

5 Perri, p. 11.

${ }_{6}$ Detskaya kniga voiny, p. 7. 
theater of history'.7 As diaries are written for private purposes, with no reader in mind, they are particularly valued by psychologists because they present the unmediated thoughts of an individual. As Jochen Hellbeck remarks, 'Analyzing a diary allows one to study forms of behavior which are difficult to reveal in any other medium'.8 However, there are caveats that come with using diaries as historical sources that historians need bear in mind. As Alexis Perri notes, writing a journal 'was an unusual act taken up by a subset of the population. They do not capture all aspects of the blockade experience.'9 Despite their limitations, Paperno stills believes that diaries, if used carefully and in the correct manner, can be of much use to scholars. One should not use the 'diary for "facts", but for the reconstruction of the social meaning of recorded daily routines, and, through them, for a glimpse into the social and emotional world inhabited by the diarist'.10

In addition to diaries, my research essay relies heavily upon memoirs that I acquired from the following books: Deti voiny (Children of War), Blokadnaia kniga (The Blockade Book) and Leningradtsy: Blokadnye dnevniki (Leningraders: Blockade Diaries). These books provided me with a compilation of memoirs and first-hand accounts written by people who survived the blockade as children. Barbara Walker notes, 'As eloquent eyewitness accounts, Soviet/Russian memoirs offer us some extraordinary glimpses into the Soviet experience'.11 However, memoirs can also pose quite a few problems for historians. For example, memoirs can 'present numerous assertions, sometimes demonstrably inaccurate'.12 Often memoirists are providing their account years after the event and so facts and events may be blurred in their memory. Because of this memoirs, are 'untrustworthy as historical sources in the simplest sense of providing objective factual evidence'.13 Nonetheless, memoirs can still be useful by historians as they 'reflect the ways that their authors, as partisans in Russian culture, view the world: how they think of the past, and how they connect with their past'.14 Barbara Walker writes that, despite some of their shortcomings, 'Soviet memoirs are far too rich in historical nuance, far too valuable to our understanding of the period, to be dismissed'.15 And as they are written in hindsight, I found the memoirs to be particularly helpful in showing the aftereffects of the blockade on children.

7 Irina Paperno, 'What Can be done with Diaries?', The Russian Review, 63.4 (2004), 561-573, p. 572.

8 Hellbeck, p. 39.

9 Perri, p. 11

10 Paperno, p. 570.

11 Barbara Walker, 'On Reading Soviet Memoirs: A History of the 'Contemporaries' Genre as an Institution of Russian Intelligentsia Culture from the 1790s to the 1970s', The Russian Review, 59.3 (2000), 327-352, p. 327.

12 Walker, p. 327.

13 Walker, p. 329.

14 Walker, p. 329.

15 Walker, p. 329. 


\section{Secondary Sources}

Soviet censorship limited what could and could not be published about the blockade, thus impacting both Soviet and Western scholarship. Untill the death of Stalin in 1953, scarcely any objective material was released on the Great Patriotic War and the blockade.

During the Khrushchev years, some of the state archives were opened to Soviet scholars. There were two pioneer works released during this period: Dmitrii Pavlov's Leningrad v blockade (Leningrad in the Blockade), published in 1958 and Alexander Karesev's Leningradtsy v gody blokady, 1941-43 (Leningraders during the Bloackade), published in 1959. During the war, Dmitrii Pavlov served as the Minister of Food Industries in Leningrad. In his work, he combines his own memories with occupational data and archival material. One chapter looks at starvation during the first year of the siege. Pavlov presents data on food rations and then discusses how these caused starvation and great hardship among the population. Although the book mentions some problems with the system experienced during the blockade, it is done with a hint of positive propaganda. This is something that is present in most works written during the Soviet Union since a positive spin was required to pass through the censor of the state.

In 1964 Khrushchev was forcefully removed from power and Leonid Brezhnev became the leader of the Soviet Union. This resulted in the 'reclassification', of many state documents and a different outlook on the Soviet past.16 The Brezhnev regime moved away from Khrushchev's deStalinization policies and developed 'the Great Patriotic myth, with its amalgamation of socialism and nationalism, which served to underscore the unity of the Soviet people'.17 The theme of heroism is prevalent during this period, entering into many written works. One of the works that I studied from this period is Deti Goroda Geroia (Children of the Hero City) a compilation of diaries, memoirs and accounts of the children of the blockade. The work presents many tragic cases all while portraying people as martyrs. These honest accounts proved to be useful for my project.

Another work I that studied from this period is Ales' Adamovich and Daniil Granin's Blokadnaia kniga (The Blockade Book), first published in 1979, towards the end of Brezhnev's

16 Richard Bidlack and Nikita Lomagin, The Leningrad Blockade, 1941-44: A New Documentary History from the Soviet Archives (New Haven, Connecticut: Yale University Press, 2013), p. 4.

17 Julie K. deGraffenried, Sacrificing Childhood: Children and the Soviet State in the Great Patriotic War (Lawrence, Kansas: University of Kansas Press, 2014), p.163. 
Stagnation period. After the war Adamovich and Granin went around to flats collecting eye-witness accounts from survivors of the siege, they collected 200 individual testimonies. This book reflects on themes that were previously unexplored, offering a far more human and honest account of the blockade.

Following the collapse of the Soviet Union in 1991, the state archives were opened to the public. This access allowed 'literary journals [to] began publishing unexpurgated siege memoirs and diaries [...] newspapers [also published] outspoken interviews with still-angry Red Army veterans and siege survivors'.18 The new materials left 'Brezhnev's mawkish fairy tale in tatters'.19 However, the early 1990s were also a frustrating time for Russian historians. There were unexplored possibilities to research, but the post-Soviet economy left many scholars so impoverished that they were financially unable to conduct research or publish any material.

The opening of the archives also presented opportunities for foreign scholars to conduct research into Soviet history. With the exception of Harrison E. Salisbury's, The Siege of Leningrad published in 1969, which presented oral accounts of emigrants from the Soviet Union, there had not been any outside research conducted on the blockade. Initially, however, Western scholars have preferred to focus on the purges and atrocities committed under Stalin during the 1930s. Only in the past decade have Western historians turned their focus towards the Blockade of Leningrad.

Notable research into the blockade by Western scholars include Anna Reid's Leningrad and Alexis Perry's The War Within. Anna Reid uses siege diaries, KGB files, letters and other archival materials. In her book, Alexis Perry looks at 125 diaries, 100 of which were previously un-published. Both authors depict the unbelievable hardship endured by those who lived through the siege. Alexis Perry theorises that because the external enemy was not visible, Leningraders were forced to fight an internal battle, both within themselves and inside the ring of the blockade: a battle to survive. Julie deGranffenried's work, Sacrificing Childhood, is one of the rare secondary sources that focuses on the plight of the children. Focusing on the Great Patriotic War as a whole, deGranffenried uses children's diaries, letters to loved ones, oral testimonies and other archival materials in her research. The study compares the childhood experiences before and after the outbreak of the war and examines the treatment of children in other WWII countries, such as Japan, the United States, Germany and Great Britain.

18 Anna Reid, Leningrad: The Epic Siege of World War II, 1941-1944 (New York: Bloomsbury Publishing USA, 2011$)$, p. 7. 19 Reid, p. 7. 
In 2007, 'President Putin's administration commissioned the publication of a handbook for history teachers that advocated instilling in Russian students pride in the Motherland'.20 This move seems to be a return to the Brezhnevite policy on the Great Patriotic War. Furthermore, on 5 May 2014, Putin's administration passed a law banning the propagation of what they consider to be 'lies about the activities of the Soviet Union in the Second World War'. Such a crime is punishable by up to five years imprisonment under article 354.1 of the criminal code 'rehabilitation of fascism'.21 This has meant that historians need to tread carefully as this law 'criminalizes the expression of certain opinions about the Soviet past'.22 Undoubtedly 'this political dabbling in history has made the lives of professional academic historians complicated, even hazardous'.23

The aim of this work is to contribute to an area of history that has previously been largely unexplored. I seek to provide further insight into the experiences of children who lived during the blockade and the impact those experiences had on their development. However, this is just one segment of a greater story about the effects of war, starvation, and trauma on the children who lived through one of the worst chapters of our history.

\section{THE END OF CHILDHOOD}

The perception of 'childhood' has changed throughout history but is generally accepted as 'the period of 'becoming' that shapes each person's opportunities later in life'. 24 There is no universal understanding of when childhood officially ends, it is largely dependent on geographical location. In poorer countries, childhood is brought to an end earlier than in the developed world. For the purpose of this study, I will define childhood as a stage in life that ends at the age of 18. The Soviet state promoted the idea of a 'Happy Soviet Childhood'. Children were important to the state because 'collectively, they represented the Soviet leadership's opportunity to shape minds, world views, and

20 Bidlack and Lomagin, p. 8.

21 Mark Edele, 'Fighting Russia's History Wars: Vladimir Putin and the Codification of World War II', History and Memory 29.2 (2017), 90-124, p. 91.

22 Edele, p. 95,

23 Ivan Kurilla, 'The "Return of Stalin": Understanding the Surge of Historical Politics in Russia' (policy memo), Ponars Eurasia (2016) <http://www.ponarseurasia.org/memo/return-stalin-understanding-surge-historical-politics-russia > .

24 Rachel Burr, Vietnam's Children in a Changing World (New Brunswick, New Jersey: Rutgers University Press, 2006$)$ p. 10. 
loyalties'.25 During the 1930s, Stalin was presented as the 'great father figure of children across the Soviet Union, crediting him with the happy and joyful childhood they enjoyed'.26

The image of happy Soviet children was completely overturned by the onset of war. Children received one of the lowest rations, highlighting how the war effort took precedence over the welfare of children. As Anna Reid notes, Though articulated as giving to each according to his needs, in practice it tended to preserve [just] the lives of those vital to the city's defence-soldiers and industrial workers - and condemned office workers, old people, the unemployed and children to death'.27 At the same time the state expected the youth to help with the war effort, 'donning the mantle of adulthood as best they could'.28 Children took on 'responsibilities at home, in factories, and in the war effort. When the war began, children helped to build fortifications and neutralize explosives as part of the local air defence.'29 Nine-year-old Liudmila Gradusova recalls how when she was at school, she 'helped to put out the petrol bombs by covering them with sand'.30

The effect that the war had on the childhood experience is poignantly expressed in Galia Zimnitskoi's diary. Before the blockade in July 1941, the 14-year-old writes, 'My friends have become obsessed with the idea of learning to dance'.31 By September the siege is in full swing. She notes how life has changed in just over a month: 'We no longer feel like playing games [...] different affairs, concerns and worries have disrupted our childhood and our previously carefree life'.32

\section{METHODS OF SURVIVAL}

During the Blockade children suffered extreme conditions of deprivation. 'Two-thirds of the population received little more than 125 grams (4.4 ounces) of bread a day-a fraction of the calories needed to sustain life'.33 The situation was made worse by an exceptionally cold winter. Pipes froze and left many without running water or heating. Il'ia Glazunov recalls the following: 'The cold was unbearable (lower than -40 degrees centigrade). We even slept wrapped up in our winter coats, hats

25 deGraffenried, p. 4.

26 deGraffenried, p. 37.

27 Reid, p. 167.

28 deGraffenried, p. 4.

29 Perri, p. 95.

30 Victoria Pimenova, ed., Deti voiny: Narodnaia kniga pamiati (Moscow: AST Publishing, 2015), p. 184.

31 Detskaya kniga voiny, p. 91.

32 Detskaya kniga voiny, p. 91.

33 Perri, p. 6. 
and scarfs. But none of this made any difference. The flat was just as cold on the inside as it was outside.' ${ }_{34}$ Children had to adapt in order to survive. As Anna Reid says, 'restraint and scrupulosity were lifesavers'.35 Eleven-year-old Anzhelina Kupaigorodskaia lived through the siege alone in her family's flat. Looking back, she attributes her survival to a list of rules left to her by her father: 'She was to wash, and to empty her slop bucket daily, never collect more than one day's ration at a time'.36 Undoubtedly, maintaining a level of normalcy in day-to-day life played a big role in survival.

Many memoirs and diaries mention the act of dividing up one's daily ration into smaller portions and eating it periodically throughout the day. By savouring the food, one could create the illusion of eating more. As Oleg Iatskevich recalls, 'The bread ration of $375 \mathrm{~g}$ divided between the three of us, was broken up into small pieces and mum would give me and my brother a piece every hour'.37 In some cases the bread was hidden away to avoid temptation. Zhanna Emil'evna writes, 'We would break the $200 \mathrm{~g}$ of bread into pieces and then hide it in a suitcase, and then we would put the suitcase under the sofa, so as to avoid eating it all at once'.38 A caregiver in an orphanage recalls watching how the children ate: 'The bread was broken up into tiny pieces and was hidden away in matchboxes. The children would save the bread, as if it were the most exquisite food, and would savour every morsel, taking hours to eat.' 39 This form of self-restraint helped people, even if just psychologically, to maintain a feeling of having three meals a day and a semblance of normalcy.

Hunger and starvation, however, caused children to obsess about food, writing extensively about it in their diaries. Fourteen-year-old Marusia Ermina writes, 'Bread is indispensable, nothing can replace it, not even chocolate, or gold. The bread that they bake is very bad, but we savour it, trying not to drop a single crumb.' 40 In another example, diarist Lena Mukhina writes an ode to a piece of chocolate: 'O! bar of chocolate, my beautiful bar of real English chocolate, where have you gone? Why did I eat you? You were so glamourous I could have just sat here and admired you, but instead I ate you, I'm such a pig!' ${ }_{11}$ Nine-year-old Tania Rudikovskoia notes in her diary the minutest details of her meager meals: 'Dinner: 3 tbsps. of Vinegret (beetroot salad), 1 sushka (small bread roll).' 42 By doing

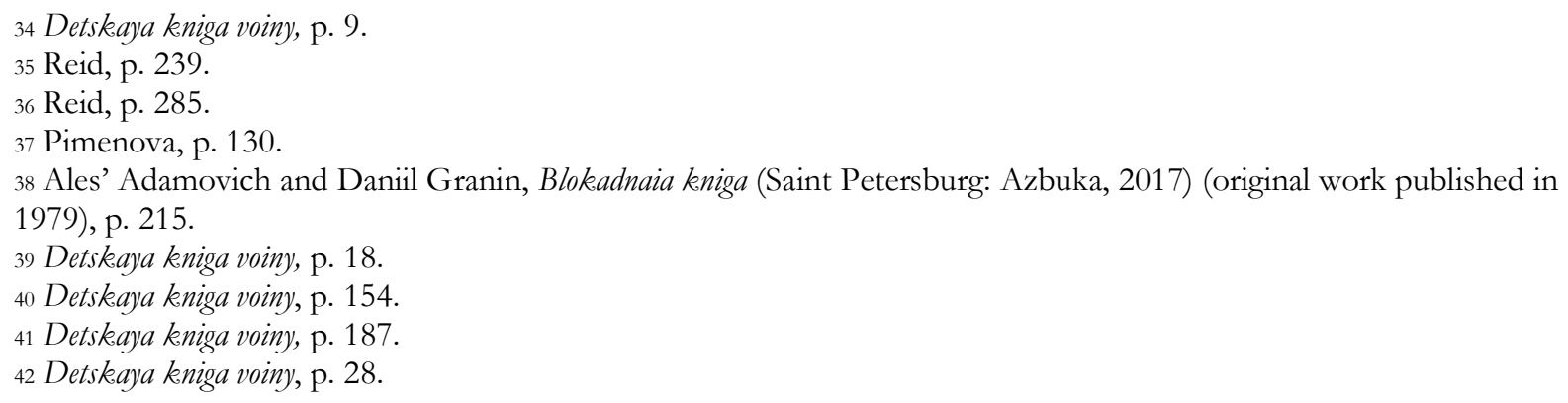


so, Ivanushkina explains that it's as if 'Tanya was trying to hold on to the feeling of a barely filled stomach for as long as possible’.43 In another diary, Iura Rybunkin writes about his food-filled dreams, 'Every night I dream about bread, butter, pies and potatoes'. ${ }_{44}$ Children found it harder than adults to overcome hunger due to their developing bodies.

The act of keeping a diary in itself played a part in helping children survive. For example, Lena Mukhina expresses her feelings of loneliness after the death of her mother: 'My God, all around me are strangers, everyone is a stranger to me, and there is no one who is close to me, everyone passes by me indifferently, and doesn't want to know me.' 45 She finds solace in her diary: 'My dearest friend, my Diary. You are the only one I have, my only counsellor. I will confide in you all my sorrows, troubles and grievances.' 46 Thus, her diary became more than an inanimate object, but a 'friend' and confidant. It helped her to feel less alone. Granin writes about the importance of diaries: 'One doesn't just write in a diary; one speaks to it. There isn't anything in the world closer than this book.' 47 For fourteenyear-old Lera Igosheva, her diary became a companion that she carried with her wherever she went. 'It comforts me and gives me courage', she writes.48 She started the diary a year before the outbreak of war and so it became a surviving link to a happier time. She writes, 'Now, the two most important things that are left in my life are my mummy and this two-year-old diary'.49

At age 12, one's ration was cut from a 'child's' ration to a 'dependent's' ration. This made daily life particularly difficult. Pavlov explains: 'Their ration was cut at a time when the child was growing up, and was required to take onto their weak shoulders more demanding jobs, helping parents with chores and responsibilities around the house.' ${ }_{50}$ During the harshest period of the winter, children and dependents would both receive $125 \mathrm{~g}$ of bread. However, children received on average 684 calories, from additional meat, grains, and sweets. Whereas, dependents only received an average of 466 calories worth of food. Workers meanwhile received 581 calories.51 The reduction of food, just as the teenage body was starting to develop, compelled many to leave school and enter the workplace so that they could receive the higher worker's ration. This essentially signified the end of their childhood.52

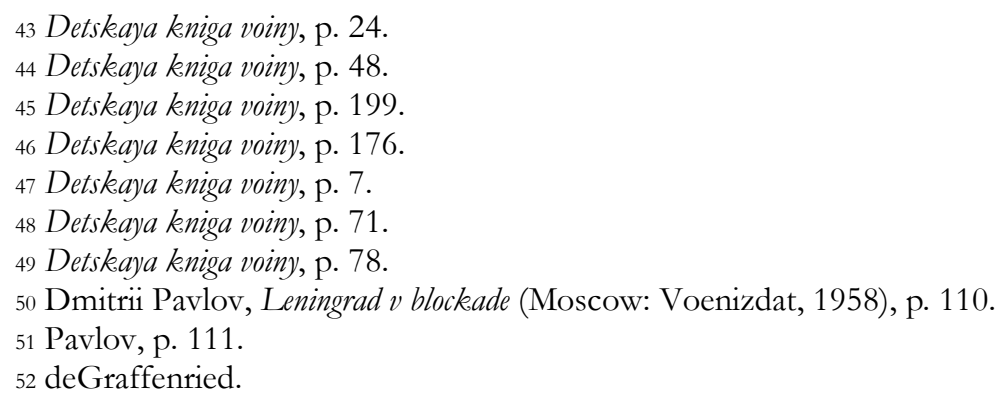


Many teenagers enrolled in trade schools, some willingly, others were forced by the state. For example, at age 14 orphans were kicked out of children's homes and sent to trade schools. There teenagers worked 'up to eleven hours a day'.53 The work was laborious and made even more difficult on only 581 calories a day. To make matters worse, conditions in trade schools were notoriously bad. In his inspection report to the Gosudarstvennyj komitet oborony

(GKO) (State Defence Committee), N. Kosygin describes the bitter reality within trade school No. 33: 'All the students were lice ridden and slept two and three to a bunk. Their dorms were filthy and sick students were not separated from the rest.' 54 Unsurprisingly, the mortality rates at some of the trades schools are estimated to have reached 'a staggering 95 percent'.55 Thirteen-year-old Valentin Poliakov recalls his experience of working in a factory, 'We sat there in silence in front of the stove, occasionally shifting from one position to another in an attempt to warm ourselves. Half an hour later, just as silently we would make our way back to the work bench, and having made a couple components, we would return to the stove.' 56 Teenage workers were expected to fulfil the quotas regardless of physical wellbeing.57

\section{Physical Change}

Leningrad children received just a fraction of the necessary daily calories and nutrition required for healthy living. To put this into perspective, on average, healthy 'seven- to eleven-year-old boys need 1,970 calories a day, girls [need] 1,740, with teenagers needing 2,220 and 1,845 [calories, respectively].'58 However, most were 'reduced to an input of 500 to 600 calories a day.' 59 In the harshest months of winter, dependents and children were receiving $125 \mathrm{~g}$ of bread. 'One hundred grams of good brown bread supply about 210 calories — with 57 grams of carbohydrates, 11 grams of protein, 2.3 grams of fat and 1.5 grams of fibre - and this bread was very far from good.' ${ }_{60}$ The bread consisted of only 40 percent flour, the rest was just filler such as saw dust and clay that contained next to no nutritional

53 Bidlack and Nikita Lomagin, p. 278.

54 Bidlack and Nikita Lomagin, p. 279.

55 Reid, p. 281.

56 Leonid Panteleev, Aleksandr Krestinskii, and Udith Broditskaia, Deti goroda geroia (Saint Petersburg: Lenizdat, 1974), p. 148.

57 Panteleev, Krestinskii, Broditskaia, p. 148.

58 Brian Moynahan, Leningrad: Siege and Symphony (New York: Grove Atlantic, 2015), p. 213.

59 Moynahan, p. 213.

60 Moynahan, p. 213. 
value.61 All of this had negative consequences on the growing bodies of children, causing stunted growth. Elena Kozhina 'stopped growing during her years as a Leningrader and an evacuee, though she was only ten years old'.62

Starvation also erased conventional markers of sex and age. Granin writes, 'It became impossible to tell if someone was male or female, old or young. Everyone walked around like phantoms.' ${ }_{3}$ People suffered from dystrophy, or the wasting away of body tissue due to starvation and malnutrition.64 In their diaries, children wrote about how their bodies were changing and how they were beginning to look more and more like old people. Perri explains how hunger can age a person: 'Starvation shrinks the body, darkens the skin, makes bones brittle.' 65 In her diary, the 12-yearold Nina Ivanovna writes about her elderly appearance, 'My face looks so old. My eyes are sunken in and swollen. I am now treated as a grown up, and no one perceives me as a child.' ${ }_{6}$ Children were often mistaken for the elderly, as they 'acquired the arthritic gait and stooped posture associated with agedness. They hunched over and leaned on canes for support.' ${ }_{77}$ Zinaida Kuznitsova remembers an incident when she and her mother went to see a doctor: 'The doctor looked at me in surprise and asked my mum: "How old is she?!” Mum replied “14”. The doctor had thought I was an old woman.' 68 Thirteen-year-old Galina Marchenko, only fully realised the extent to which her appearance had changed when she returned to her village after evacuation. She remembers an experience when she sees a friend she knew before the war:

She turned to me and asked: 'Excuse me babushka (grandmother), do you know where Galia is?'

'Kliania,' I said, 'It's me Galia.'

She burst into tears and said: 'I didn't recognize you.' 69

Another physical sign of aging was facial hair growth. Ol'ga Mel'nikova describes what she saw when she worked at an evacuation point near Lake Ladoga:

61 Nikolai Shumilov, $V$ dni blokadi (Moscow: Mysl, 1974), p. 121.

62 deGraffenried, p. 24.

63 Adamovich, p. 6.

64 Moynahan, p. 243.

65 Perri, p. 45.

66 Panteleev, Krestinskii, Broditskaia, p. 166,

67 Perri, p. 46.

68 Irina Muravyova, Leningradtsy: blokadnye dnevniki (Saint Petersburg: Lenizdat, 2014), p. 29.

69 Adamovich, p. 229. 
It was often the case that, these children would have facial hair growth [...] Yes, we used to call them, little old people. When these children were brought to us, they had a complete lack of strength, will and mobility, not like the children we have today.70

The hair growth was as a result of the child's body being subjugated to extreme starvation at a time when it is undergoing physical changes. This caused a hormonal imbalance in which instead of becoming dormant, many tissues, notably hair roots and intestinal mucosa, continue[d] to multiply and produce grossly defective cells'.71

Parents were often shocked and upset by the physical change in their young children. When Sergei Miliaev returned from the front in February 1942, he found that his six-year-old son had 'become a "little-old person" a "dwarf". 72 Sergei describes in his diary how his son, Shurik, is a shadow of the boy he left behind before the war. 'Now he is in his winter coat,' he writes, 'all swollen up, pale, just skin and bones, and only a pair of black beady eyes that recall the rosy-faces Shurik that I once knew.'73 Likewise Aleksandra Liubovskia describes her sorrow when she sees the state of her son's body as she washes him in the bathhouse: 'Only bones are left. A sunken-in stomach, ribs jutting out pointedly, the bones of the pelvis are outlined sharply.' 74 There were instances when parents were stunned by the physical similarities between them and their children. With great sadness, Aleksandra Liubovskaia noted how she and her daughter Natasha, 'more than twenty years her junior, now appeared to be the same age; both were "wrinkled and grey haired"”.75

Leningrad scientists researching into the effects of starvation found that 'Vitamin B1 (thiamine) deficiency could slow reflexes and weaken muscles in the legs, fingers, and toes, making it very difficult to control and move one's body'. ${ }_{76}$ Children wrote in their diaries about how every movement was a struggle. Iura Rybunkin writes, 'I have become so weak and weary, that even my hand shakes as I write this, as I walk, my knees feel weak, and with each step I fear that I could collapse.' 77 Similarly Lena Mukhina describes the struggle of standing up: 'I am not even exaggerating,

70 Adamovich, p. 233.

71 George Graham, 'Starvation in the Modern World', The New England Journal of Medicine, 328 (1993) 1058-1061, p. 1058.

72 Adamovich, p. 242.

73 Adamovich, p. 242.

74 Perri, p. 157.

75 Perri, p. 45.

76 Perri, p. 59.

77 Detskaya kniga voiny, p. 48. 
when I say: I need to exert a huge amount of effort when I attempt to stand up, after an extensive period of sitting.' 78 She reflects later on the absurdity of the situation in which she finds herself: 'Honestly, it's almost comical, I mean, I am neither disabled, nor elderly-I am a young woman, in the prime of her life, with everything to live for.' 79 This account presents the whole horror of aging ahead of your time.

\section{Mental Change}

Hunger and malnutrition also affected children mentally. Children became more somber and serious, traits that are not usually associated with childhood. L. Mandrykina, who worked in a children's home, recalls, 'For a while they were like all other children, they remained cheerful and inquisitive [...] then suddenly they became the quietest children in the world'.80 A caregiver of 100 children at another home made a similar observation: 'For hours on end, they just sit there motionless and silent'.81 Glafira Korneeva reported that the 'children simply lay on their bunks, unable to sit up and too exhausted to cry or even whine'.82 Starvation took away the lightheartedness of childhood. For example, during the 1942 New Year's celebrations for school children, Zhanna Emil'evna, a first grader, recalls how they all sat uninterested watching a magician. 'How apathetic we all were as we sat there,' she writes. 'Until we couldn't take it any longer and one of us asked: 'Will we have dinner soon?" That's how little childish spirit was left in all of us.' 83 Another schoolchild, Leonid Popov, doesn't recall any details about the concert, but remembers the exact quantities of food they were given: 'They served us turnip soup, a small burger, with vegetables for the main, and fruit jelly from concentrate for dessert. They also gave out 18 chocolate coated raisins each.' 84 These two accounts serve to present the extent to which conventional childish behaviour had been changed by the Blockade.

Teachers also noted a change in children's behaviour. As Lidiia Usova recalls, 'During that winter, the children of Leningrad forgot how to play and have fun, and even forgot how to smile and

78 Detskaya kniga voiny, p. 191.

79 Detskaya kniga voiny, p. 202.

80 Adamovich, p. 210.

81 Detskaya kniga voiny, p. 18.

82 Perri, The War, p.133

83 Adamovich, p. 231.

84 Adamovich, p. 233. 
laugh.' 85 After the siege, teachers were overjoyed when they started to notice typical childish behaviour again, like teasing and playing tricks. It was a sign that the children were recovering. Irina Kireeva remembers an incident in Autumn of 1942 when she and her friend played a prank and then were called into the head teacher's office. 'We went to see the head teacher, and suddenly she started to cry [...] I now understand why-our teachers were overjoyed because this was our first childish prank', she writes.86 Another sign of recovery was laughter. Aleksandra Agronskaia recalls the reaction of her teacher, Elena Ignat'evna at school No. 202, when 'the whole class, spontaneously burst into laughter. After the school day was over, Elena Ignat'vna went round to all the parents houses telling them: "Your children laughed today!" 87 The teacher saw the children's laughter as an event of such importance that she had to report it to the parents.

During the blockade, children also developed a fear for the future and an unusual pessimism. Lera Igosheva writes in her diary, 'What an uncertain time it is, who knows what is to become of us in a month, in a year?' 88 Children noticed how others were changing and worried about what might happen to them. Kapa Voznesenskaia notes, 'Mother has come home-I notice that she has grown even thinner'.89 Worried about her mother, Lena Mukhina writes, 'I am very fearful for my mum's wellbeing. God only knows how she must be feeling, if I am already starting to stagger around from weakness.'90 Iura Rybunkin admits that he lives with a constant concern for his mother and sister's wellbeing: 'Not a day goes by that is not overshadowed by hunger, and fear for my mum and Irina's lives'.91

During the siege, it was common for children to become caregivers to their parents who were too exhausted and ill to move. Irina Zelenskaia worked in the department for the settlement of military families. In her work, she profiled local children 'who were supporting their families virtually on their own'.92 For example, 13-year-old Olia Lebedeva looked after her ill mother, father and little sister. She describes the arduous task of caring for the whole household in her memoirs: 'It was really hard for me, but I did everything patiently: I would wake up early in the morning, chop firewood, light a fire, boil some water, prepare the warming pans for the sick, empty the bucket and bring water.' 93 Thirteen-

85 Adamovich, p. 211.

86 Adamovich, p. 220.

87 Adamovich, p. 212.

88 Detskaya kniga voiny, p. 71.

89 Detskaya kniga voiny, p. 107.

90 Detskaya kniga voiny, p. 191.

91 Detskaya kniga voiny, p. 53.

92 Perri, p. 96.

93 Panteleev, Krestinskii, Broditskaia, p. 160. 
year-old Zinaida Kuznetsova recalls coming home from work to find her mother lying in a halfconscious state. 'When I got home I would be greeted by a sorry scene,' she writes. 'My mum was lying there in a semi-conscious state. I would get out my precious ration and would quickly try and put the food in her mouth.' 94 A definite role reversal is seen in the diary of 14-year-old Kapa Voznesenskaia. She describes how she would pick her exhausted mother up from work and pull her back home on a sled, like parents used to do for children after school. 'She would hobble her way to work with a walking stick in the morning' she writes. 'And then I would come and pick her up from work, pulling her back on the sled.'95 Mira Petrova recalls how much she matured in the first blockade winter. Even at the age of six she realized that she needed to take on more responsibility: 'I was still a spoilt child, who still needed the help of her grandma to get dressed in the summer of 1941, but by the spring of 1942, I was completely independent and helped my mum out with everything.'96

Older children were often expected to stand in the lines for the family's food rations. They started queuing as early as 4 a.m. and could stand in line for as long as 12 hours, with no guarantee they would receive anything when they got to the front.97 The children often complained about having to stand in the queues for food, but they also acknowledged that they had a duty towards their loved ones and accepted the extra weight that was on their shoulders. Iura Rybunkin writes, 'I had to go and queue again, but without success. I am completely aware that I am the only one in my family who can get food and bring the three of us back to life. But I just don't have the strength or energy to do so.'98 Galina Marchenko, 13, queued for hours in the freezing cold in order to get food for her mother: "We stood in queues from nightfall, sometimes for days on end, we would put on all the clothes we owned. But Mum couldn't move, she somehow became weaker quicker than us.'99 As the only mobile member of her family, 13-year-old Zinaida Kuznetsova, was tasked with picking up the family's ration cards from Vasil'evskii Ostrov, where they were registered. The trip took her two days. During the entire journey, she was keenly aware that the fate of family was in her hands. Upon arriving back home, she was met with devastating news: 'Grandma hadn't survived the wait and died before I managed to get back. Mum was worried that I had died in the frost, of course without my help she would have had no hope for survival.' 100 'This is a huge responsibility to be placed on one so young.

94 Muravyova, p. 33.

95 Detskaya kniga voiny, p. 127.

96 Pimenova, p. 52.

97 Moynahan.

98 Detskaya kniga voiny, p. 49.

99 Adamovich, p. 211.

100 Muravyova, p. 25. 
Parents were faced the heart-wrenching decision of whether to feed themselves or their children. 'That many or most prioritised their children is indicated by the large numbers of orphans they left behind,' explains Reid.101 Many children faced the trauma of outliving their parents and having to bury their loved ones. Thirteen-year-old Tania Vassoevich organised the burial of her mother and little brother by herself. 'Mum and Vova are buried in real coffins, which I managed to exchange for bread,' she writes 102 The scholar Harrison Salisbury elaborates, 'Individual graves were almost impossible to obtain. They were obtainable only for bread, the most precious of Leningrad commodities.' 103

Children developed a hardened outlook onto life, describing the death of family members with little emotion. A particularly striking example of this is in nine-year-old Tania Rudykovskaya's diary: 'We had a bone broth for supper. Uncle Fedia died. Mama came back from town and brought: $200 \mathrm{~g}$ of bread for papa, and a small piece of chocolate for me and Gelia.' 104 Daniil Granin explains that this was a survival method. The child's psyche did not allow the brain to properly process the information in order to save them from trauma.105

Another side effect of starvation was a developed inability to concentrate. A study on the effects of starvation found that patients 'had an increased fixation on food and suffered from severe hunger pangs that distracted their attention from manual or intellectual pursuits. They lost the ability to concentrate.'106 Misha Tikhomirov complained about the inability to concentrate in his diary: 'The general weakness in the body is also affecting my brain, which is refusing to work properly, I can't concentrate.' 107 Similarly, Marusia Eremina writes, 'I keep feeling dizzy, in our lessons we all sit there like fools, making the most elementary mistakes'.108 Irina Kireeva recalls the frustration of learning at school, 'I remember, my maths teacher trying to explain a really elementary sum to us. She kept trying, and trying to explain it, but still I couldn't get it. We couldn't even learn how to count to 20.'109

101 Reid, p. 213.

102 Detskaya kniga voiny, p. 84.

103 Harrison E. Salisbury, The 900 Days: The Siege of Leningrad (London: Secker \& Warburg, 1969), p. 437.

104 Detskaya kniga voiny, p. 26.

105 Adamovich.

106 Graham, p. 1058.

107 Detskaya kniga voiny, p. 142.

108 Detskaya kniga voiny, p. 155.

109 Adamovich, p. 219. 


\section{AFTEREFFECTS OF THE BLOCKADE}

The psychological and physical aftereffects of the Blockade were felt long after the war ended.

DeGraffenried explains that 'despite attempts to equate victory with pre-war normalcy, the post war period was anything but normal for children. Life remained difficult during the reconstruction.' 110 Those who survived the blockade were troubled with dark childhood memories. Oleg Iatskevich, who was six during the blockade, recalls the feelings of that time with an emotional vividness: 'It is terrible, when you are lying there in the darkness, freezing, and all you can hear is the harsh ticking of the metronome111 slowly and relentlessly ebbing away the seconds of your life.'112 For Lidia Sovrora there are two associations with her childhood: 'The relentless sound of the metronome day in and day out, and darkness.' 113 These are bleak memories from a period of life that is typically associated with joy and light-heartedness.

The blockade had long-lasting effects on children, many of whom suffered from posttraumatic stress disorders and anxiety as they got older. In 1942, the psychiatrist B.E Maksimov of the Bekhterev Institute claims that 'the siege increased the frequency and above all the acuteness of mental disease'.114 DeGraffenried notes that the '1953 manual on trauma management affirms the existence of lingering psychological problems' due to the siege.115 Trauma caused some children to develop speech impediments. For example, Il'ia Glazunov recalls, 'After the blockade my stammer was so pronounced, that I needed to respond in written form instead of speaking'.116 He says that the blockade had negatively affected not only his childhood, but the rest of his life. 'My whole life is a reflection of the consequences of war - that terrible tragedy,' says Glazunov. '[And] not only I, but the whole generation of war children are affected by that terrible time.' 117 The scholar deGraffenried agrees: 'Today, the war children are in their seventies and eighties, suffering, often silently, from post- traumatic stress disorder, depression, social phobias, and lingering physical effects of wartime scarcity.' 118

110 deGraffenried, p. 12.

111 During the Blockade, when there were no radio broadcasts, there would be the sound of the metronome coming through the speaker.

112 Pimenova, p. 132.

113 Pimenova, p. 186.

114 Perri, p. 26.

115 deGraffenried, p. 26.

116 Detskaya kniga voiny, p. 11.

117 Pimenova, p. 12.

118 deGraffenried, p. 170. 
The blockade had long lasting physical as well as psychological effects. Studies suggest that on average the Leningrad children lost about two years from their life expectancy.119 Survivors are also more susceptible to diseases. Other research found that 'starvation during the Leningrad siege, with its accompanying stress and trauma, resulted in raised systolic and diastolic blood pressure, which was evident even three decades after the event'.120 This increases the chance of developing heart problems later in life. Another possible consequence of prolonged periods of starvation was seen in the increase of 'infant mortality [rates] that occurred in 1970s which might partially be attributed to the mother having been "nutritionally deprived" in her formative years'.121

To summarize, the Leningrad children suffered unparalleled deprivation during the war. The State was no longer able to maintain its policies for a 'Happy Soviet Childhood'. Children became uncharacteristically serious and sombre as they were forced to mature ahead of their years, shouldering an unprecedented level of responsibility. The blockade caused the children to show physical signs of aging beyond their years. Starvation and malnutrition also resulted in stunted growth, brittle bones and inhibited brain functions. The blockade's aftereffects were felt long after the end of the war. It could be said that the scars never truly healed as many still struggle with post traumatic disorders and other mental and physical ailments.

This work is licensed under a Creative Commons Attribution 4.0 International License. This license lets it to be freely shared and adapted in any medium and format and for any purpose, including commercially. To view a copy of this license, visit https:// creativecommons.org/licenses/by/4.0/.

119 deGraffenried, p. 25.

120 Pär Sparén and others, 'Long term mortality after severe starvation during the siege of Leningrad', British Medical Journal, 328:7430 (2004), 11-14, p.14.

121 deGraffenried, p. 25. 


\section{REFERENCES}

Adamovich, Ales' and Daniil Granin, Blokadnaia kniga (Saint Petersburg: Azbuka, 2017) (original work published in 1979).

Bidlack, Richard and Nikita Lomagin, The Leningrad Blockade, 1941-44: A New Documentary History from the Soviet Archives (New Haven, Connecticut: Yale University Press, 2013).

Burr, Rachel, Vietnam's Children in a Changing World (New Brunswick, New Jersey: Rutgers University Press, 2006).

deGraffenried, Julie K., Sacrificing Childhood: Children and the Soviet State in the Great Patriotic War (Lawrence, Kansas: University of Kansas Press, 2014).

Detskaya kniga voiny, ed. by Nikolay Zyatkov, Evgeny Faktorovich, Tatyana Kuznetsova, Polina Ivanushkina, and others (Moscow: Argumenty i Fakty, 2016).

Edele, Mark, 'Fighting Russia's History Wars: Vladimir Putin and the Codification of World War II', History and Memory 29.2 (2017), 90-124.

Graham, George, 'Starvation in the Modern World', The New England Journal of Medicine, 328 (1993) 1058-1061.

Hellbeck, Jochen, Revolution on my mind (Cambridge, Massachusetts: Harvard University Press, 2006).

Karesev, Alexandar, Leningradtsy v gody blokady, 1941-1943 (Saint Petersburg: USSR Academy of Sciences Publishing House, 1959). 
Kurilla, Ivan, 'The "Return of Stalin": Understanding the Surge of Historical Politics in Russia' (policy memo), Ponars Eurasia (2016) < http://www.ponarseurasia.org/memo/return-stalinunderstanding-surge-historical-politics-russia>

Moynahan, Brian, Leningrad: Siege and Symphony (New York: Grove Atlantic, 2015).

Muravyova, Irina, Leningradtsy: blokadnye dnevniki (Saint Petersburg: Lenizdat, 2014).

Panteleev, Leonid, Aleksandr Krestinskii and Udith Broditskaia, Deti goroda geroia (Saint Petersburg: Lenizdat, 1974).

Paperno, Irina, 'What Can be done with Diaries?’, The Russian Review, 63.4 (2004), 561-573.

Pavlov, Dmitrii, Leningrad v blockade (Moscow: Voenizdat, 1958).

Perri, Alexis, The War Within (Cambridge, Massachusetts: Harvard University Press, 2016).

Pimenova, Victoria, ed., Deti voiny: Narodnaia kniga pamiati (Moscow: AST Publishing, 2015).

Reid, Anna, Leningrad: The Epic Siege of World War II, 1941-1944 (New York: Bloomsbury Publishing USA, 2011).

Salisbury, Harrison E., The 900 Days: The Siege of Leningrad (London: Secker \& Warburg, 1969).

Shumilov, Nikolai, $V$ dni blokadi (Moscow: Mysl, 1974).

Sparén, Pär and others, 'Long term mortality after severe starvation during the siege of Leningrad', British Medical Journal, 328:7430 (2004), 11-14.

Walker, Barbara, 'On Reading Soviet Memoirs: A History of the 'Contemporaries' Genre as an Institution of Russian Intelligentsia Culture from the 1790s to the 1970s', The Russian Review, 59.3 (2000), 327-352. 
This work is licensed under the Creative Commons Attribution-NoDerivatives 4.0 International License. To view a copy of this license, visit http://creativecommons.org/licenses/by-nd/4.0/ or send a letter to Creative Commons, PO Box 1866, Mountain View, CA 94042, USA. 